\title{
Colds as predictors of the onset and severity of COPD exacerbations
}

\author{
This article was published in the following Dove Press journal: \\ International Journal of COPD \\ 10 March 2017 \\ Number of times this article has been viewed
}

\author{
Neil W Johnston' \\ Marita Olsson ${ }^{2}$ \\ Staffan Edsbäcker ${ }^{3}$ \\ Maria Gerhardsson de \\ Verdier ${ }^{4}$ \\ Per Gustafson ${ }^{5}$ \\ Christopher $\mathrm{McCrae}^{3}$ \\ Peter V Coyle \\ R Andrew Mclvor \\ 'Department of Medicine, Firestone \\ Institute for Respiratory Health, \\ McMaster University, Hamilton, ON, \\ Canada; ${ }^{2}$ Early Clinical Development \\ Biometrics, ${ }^{3}$ Respiratory, Inflammation \& \\ Autoimmunity Unit, Innovative \\ Medicines \& Early Development, \\ ${ }^{4}$ Medical Evidence and Observational \\ Research Centre, ${ }^{5}$ Respiratory, \\ Inflammation \& Autoimmunity \\ Translational Medicine Unit, Early \\ Clinical Development, Innovative \\ Medicines \& Early Development, \\ AstraZeneca Research and \\ Development, Gothenburg, Molndal, \\ Sweden; ${ }^{6}$ Regional Virology Laboratory, \\ Belfast HSC Trust, Belfast, UK
}

Correspondence: Neil W Johnston Department of Medicine, Firestone Institute for Respiratory Health, McMaster University, 50 Charlton Avenue East, Hamilton, ON L8N 4A6, Canada

Tel + I 90553769 II

Email njohnsto@mcmaster.ca
Rationale: Common colds are associated with acute respiratory symptom exacerbations in COPD patients.

Objective: To determine exacerbation risk and severity in COPD patients with/without coincident self-reported colds.

Methods: Global initiative for chronic Obstructive Lung Disease stage I-IV COPD patients electronically transmitted respiratory symptom diaries to research staff daily between December 2006 and April 2009. Respiratory symptom worsening prompted contact by a study nurse and patient assessment to determine if a cold was present or an exacerbation underway. A composite daily symptom score was derived for each subject from diarized symptom data. The exacerbation/ cold/virus relation was examined using a Poisson regression model, the relation of colds to respiratory symptom severity using generalized estimating equation models.

Results: Daily diary transmission compliance of $>97 \%$ enabled detection of all possible exacerbations. Among 262 exacerbations meeting Anthonisen criteria, 218 (83\%) had cold-like symptoms present at their inception, but respiratory viruses were detected in only $106(40 \%)$. Within-subject exacerbation risk was 30 times (95\% confidence interval [CI]: 20, 47; $P<0.001$ ) greater with colds present. Compared to cold- and virus-negative exacerbations $(n=57)$, the mean increase in composite symptom score in those cold and virus positive ( $\mathrm{n}=79)$ was 0.93 (95\% CI: $0.61,1.25 ; P<0.001)$, cold-positive and virus-negative exacerbations ( $\mathrm{n}=100) 0.51$ (95\% CI: $0.21,0.81 ; P<0.001)$, coldnegative and virus-positive exacerbations ( $\mathrm{n}=26) 0.58$ (95\% CI: $0.23,0.94 ; P<0.001)$.

Conclusion: This study emphasizes the importance of colds in COPD exacerbation risk and severity, even in the absence of virus detection. COPD patients should act promptly when cold symptoms appear to facilitate early intervention for exacerbation prevention or management.

Keywords: COPD exacerbations, respiratory infection, COPD epidemiology, respiratory viruses, common cold

\section{Introduction}

The frequency of COPD exacerbations is an important determinant of the costs of care of COPD patients. ${ }^{1}$ Over a 2-year period, those having no exacerbations had COPD-related health care costs of $\$ 1,605$ while those having three or more had costs of $\$ 12,257$. The frequency of prior COPD exacerbations is the best predictor of the risk of future exacerbations, and a frequent exacerbator phenotype has been posited. ${ }^{2}$ COPD exacerbations are commonly associated with both viral, ${ }^{3-8}$ most often rhinovirus, ${ }^{5-9}$ and bacterial ${ }^{10}$ respiratory infections (RIs). COPD exacerbations associated with symptoms of a cold have been shown to have longer recovery times and more sudden onset ${ }^{11,12}$ than those without cold symptoms, and COPD patients having more frequent exacerbations experience nearly double the number of colds compared to patients experiencing fewer exacerbations. ${ }^{13}$ The frequent exacerbator phenotype has been suggested to be related 
to increased susceptibility to RI and occurs with comparable frequency across levels of COPD severity. ${ }^{2,14}$

Between December 2006 and April 2009, we conducted a two-phase observational study to evaluate the use of electronic capture and transmission of daily health diaries by COPD patients. In Phase 1 (December 2006 to April 2007), data were submitted by patients via fax and in Phase 2 (December 2007 to April 2009) via BlackBerry smartphones. ${ }^{15,16} \mathrm{We}$ showed that compliance with each day's diary completion and transmission exceeded 97\% with fax and 99\% using BlackBerrys, and that all COPD exacerbations that occurred were detected at their inception.

Given a data set from a cohort of COPD patients of mixed severity that had near complete daily respiratory symptom data and reported cold incidence, we wished to examine the relation of colds to respiratory symptom worsening and whether the appearance of a cold in a COPD patient is a risk factor for exacerbation. Complete data enabled quantification of the increased risk of exacerbation associated with the presence of a cold.

\section{Methods}

\section{Study design}

The results reported herein are derived from a two-phase prospective observational study of COPD patients of mixed disease severity over a maximum period of 22 months between December 1, 2006, and April 30, 2009. Other results have been previously reported. ${ }^{15,16}$

\section{Study participants}

Study participants were recruited from the clinics of respiratory specialists or referred by primary care physicians in the region of Hamilton, ON, Canada. The study was approved by the Research Ethics Board of St Joseph's Healthcare, Hamilton (RP07-2864). All participants provided written informed consent to be entered into the study.

\section{Subject inclusion and exclusion criteria}

The inclusion criteria were: age $\geq 40$ years; ability to communicate in English; COPD diagnosis and meeting criteria for Global initiative for chronic Obstructive Lung Disease (GOLD) stages I-IV classification; current or ex-smoker with a minimum 10 pack-years of exposure; previous demonstration of $<20 \%$ reversibility in forced expiratory volume in 1 second $\left(\mathrm{FEV}_{1}\right)$ or an increase in $\mathrm{FEV}_{1}$ of $<200$ $\mathrm{mL}$ after inhalation of $200 \mu \mathrm{g}$ of salbutamol; prepared to provide informed consent; residing in noninstitutional domicile without current plans to transfer to institutional care; for the fax phase participants, having an emergency department visit in the previous year for a breathing problem.

The exclusion criteria were significant comorbidity that would interfere with the participant's ability to complete the study protocol, including use of a data transmission device; planning to be absent from the study catchment area for a significant part of the study; and history of asthma or seasonal allergic rhinitis.

Participants meeting the inclusion criteria underwent a baseline assessment including clinical history, spirometry, BODE (Body mass index, airflow Obstruction, Dyspnea, and Exercise capacity) index calculation, completion of the St George's Respiratory Questionnaire, collection of samples of sputum and nasal brushings for virological testing, and blood for measurement of C-reactive protein concentration. During the study, participants' medical care remained with their own physicians.

\section{Data collection and detection of COPD exacerbations}

At enrollment, participants were provided with and trained in the use of either a fax machine or a model 8700 BlackBerry Smartphone (BlackBerry, Waterloo, ON, Canada). Functions of the devices not needed for the study were disabled. Both fax and BlackBerry diary data were transmitted daily to a study server. Participants completed test questionnaires under the supervision of study nurses to ensure that they could interpret questions correctly and consistently. Participants could initiate contact with study nurses at any time during the study through a flag in the daily diary if they had questions about use of the devices or uncertainty about how to report a change in their health. Flags were programmed to alert staff when one or more symptoms moved up two levels of severity on a given day, any symptom reached its worst level on a given day, a participant reported a health-system encounter for a respiratory problem, reported cold-like symptoms (CLS) on any day, had not transmitted two sequential daily diaries, or requested contact by staff. The fax phase questionnaire is provided in Figure S1, that for the BlackBerry phase in Table S1.

Participants whose diaries met one of the above criteria were contacted by a study nurse and asked using lay terminology to confirm whether they thought their breathlessness was worse than in usual day-to-day variation; they had an increase in sputum volume and/or sputum purulence; and/or medical attention was sought for "breathing problems"; and/or they had the symptoms of a cold.

If a new possible exacerbation and/or the presence of a cold was confirmed during telephone contact, an encounter 
in the participant's home with a study nurse was scheduled as soon as possible. In $81 \%$ of encounters, this occurred within 72 h. During encounters, participants underwent post-bronchodilator spirometry (SpiroPro; BTL Medical Technologies Canada, Inc., East York, ON, Canada) and had specimens of spontaneously produced sputum and nasal brushings (both nostrils pooled) taken for virological analysis. BlackBerry study participants were notified that three supplementary questions (Table S1) would appear in their diary to determine if prednisone or an antibiotic were taken or if breathing had returned to normal on a given day. When this occurred, supplementary questions were removed from the daily diary by remote command.

During hospitalizations, staff conducted an encounter with the participants as soon as medically acceptable. With the approval of attending physicians, BlackBerry phase participants continued their diary submissions while in hospital.

\section{Assessment of exacerbations}

Specialist respiratory nurses assessed the severity of COPD exacerbations using the Anthonisen criteria. ${ }^{17}$

\section{Definition of colds}

We defined a cold as occurring when $\geq 2$ days of CLS were reported by participants through a positive response to question 5 in the fax phase or question 6 in the BlackBerry phase (Figure S1 and Table S1). Once a cold was defined to have started, at least 2 days of no CLS were required for it to be ruled to have ended. Thus, a single CLS-free day occurring after $\geq 2$ days with CLS and followed by a day with CLS was counted as part of the cold period. Periods of 1 day of CLS were not counted as colds but were used for the calculation of the sensitivity of CLS presence for predicting an exacerbation.

\section{Diary symptom scoring}

The diary questions used in the fax (Figure S1) and BlackBerry (Table S1) studies differed. The primary purpose of the questionnaire in both study phases was to detect the onset of a COPD exacerbation or CLS. The questionnaire for the BlackBerry phase incorporated modifications gained from experience in the fax phase, and in part to accommodate engineering of the BlackBerry-based data collection process.

For the analyses in the present report question, responses have been scored as follows: for the fax phase: Presence of cough - no cough $=0$, mild cough $=1$, moderate $\operatorname{cough}=1$, severe $\operatorname{cough}=2$, very severe $\operatorname{cough}=2$.
Presence of shortness of breath $(\mathrm{SOB})-$ no $\mathrm{SOB}=0$, mild $\mathrm{SOB}=1$, moderate $\mathrm{SOB}=1$, severe $\mathrm{SOB}=2$, very severe $\mathrm{SOB}=2$.

How much phlegm did you cough up - none $=0$, less than usual $=1$, usual amount $=1$, more than usual $=2$, much more than usual $=2$.

For the BlackBerry phase: Presence of cough - no cough $=0$, mild cough $=1$, moderate $\operatorname{cough}=1$, severe cough $=2$, very severe cough $=2$.

Presence of $\mathrm{SOB}-$ no $\mathrm{SOB}=0$, mild $\mathrm{SOB}=1$, moderate $\mathrm{SOB}=1$, severe $\mathrm{SOB}=2$, very severe $\mathrm{SOB}=2$.

Color of phlegm - none $=0$, clear, white, or milky $=1$, deep yellow or green $=2$.

The scores for cough, SOB, and phlegm quality were added together to form a daily symptom score, which was the basis for a 7-day composite exacerbation symptom severity score. The symptom severity score during exacerbations was calculated as the difference between the mean composite symptom score over a 7-day period beginning 10 days before a subject encounter occurred and the mean composite symptom score over a 7-day period starting from the day a subject encounter occurred. As both the pre-encounter and during exacerbation symptom scores have possible values between 0 and 6 , the difference between them has a possible range of between -6 and 6 .

\section{Statistical analysis}

Statistical analyses were conducted using "R" version 3.1.3 (R Foundation for Statistical Computing, Vienna, Austria). The relationship between rate of exacerbations and number of colds was investigated in a within-patient model and a population mean model. The within-subject model compared the exacerbation rate when a cold was present to the rate when the subject was cold free. The exacerbation rate ratio, within subjects who experienced at least one exacerbation and had at least one cold and one period free of colds, was estimated using a Poisson regression model with subjectspecific intercepts. The population mean model estimated the average increase in exacerbation rate per unit increase in number of colds, within all patients, using a Poisson regression model with total study time as an offset. Both Poisson models were fitted allowing for overdispersion. Season was one of four study periods: December 2006 to April 2007, December 2007 to April 2008, May 2008 to November 2008, and December 2008 to April 2009.

Exacerbations were divided into those with onset during the first 3 days of a cold, "early onset" and those with onset after $\geq 3$ days of cold duration, "late onset". The 3-day point for 
classification of early and late onset was selected based on the results of a study of experimental inoculation of COPD patients with human rhinovirus (HRV) in which upper respiratory tract symptoms reached their most severe level on day $3 .^{18}$

The mean difference in symptom score severity between exacerbations coinciding with colds and those occurring when colds were absent was estimated by a generalized estimating equation (GEE) model. Within-patient correlations were accounted for using an exchangeable covariance structure. The same type of GEE model was used to assess mean differences in severity score between virus-positive and virus-negative exacerbations. In both cases, the GEE model was adjusted for the symptom score level prior to an exacerbation event (pre-encounter score). The relationship between the severity of COPD exacerbations and colds was further evaluated in a GEE model, which in addition included GOLD stage and its interaction with cold status.

\section{Virological testing}

Virological testing was conducted as previously described in samples from nasal brushings and expectorated sputum. ${ }^{16}$

\section{Results}

\section{Recruitment of participants and participant characteristics}

For the fax phase, 46 GOLD I-IV participants provided data from December 1, 2006, to April 30, 2007. For the BlackBerry phase 49 participants, among whom 17 had participated in the fax phase, provided data between December 1, 2007, and November 30, 2008. One died during the period. The study was extended from December 1, 2008, to April 30, 2009. Forty-six of the earlier participants continued through the extension period and a further 25 were recruited. During the final study period, five participants died.

Demographic and clinical characteristics of the study participants are shown in Table 1. GOLD categories 1 and 4 had relatively small numbers of participants and have been combined with GOLD categories 2 and 3, respectively.

\section{Daily diary data and COPD exacerbations}

In the fax phase, participants completed 10,037 of 10,332 possible diaries $(97.1 \%)$. No diaries during the fax phase were completed during hospitalization. During the BlackBerry phase, participants transmitted all but 26 of 28,514 possible daily diaries including 176 of 191 during inpatient hospital days $(99.9 \%$ overall).

Consequent to diary reports of respiratory symptom changes or the presence of CLS, 267 participant encounters
Table I Demographic and clinical characteristics of the study population at enrollment

\begin{tabular}{|c|c|c|}
\hline $\begin{array}{l}\text { Participant } \\
\text { characteristics }\end{array}$ & $\begin{array}{l}\text { GOLD stages I } \\
(n=5) \text { and II } \\
(n=5 I) \text { subjects }\end{array}$ & $\begin{array}{l}\text { GOLD stages III } \\
(n=38) \text { and IV } \\
(n=14) \text { subjects }\end{array}$ \\
\hline Age, mean (range), years & $66.8(45-85)$ & $67.0(45-90)$ \\
\hline Male, n (\%) & $26(46)$ & $30(58)$ \\
\hline $\begin{array}{l}\text { Smoking, median } \\
\text { (interquartile range), } \\
\text { pack-years }\end{array}$ & $48.8(43.3)$ & $46.8(27.1)$ \\
\hline Current smokers, n (\%) & $18(32)$ & $14(27)$ \\
\hline BODE score, mean (SD) & $2.3(1.7)$ & $5.6(2.4)$ \\
\hline Dyspnea score, median & 2.0 & 3.0 \\
\hline $\begin{array}{l}\% \text { predicted FEV, post- } \\
\text { bronchodilator, mean (SD) }\end{array}$ & $63.3(12.0)$ & $35.6(8.9)$ \\
\hline $\begin{array}{l}\text { Six-minute walk distance, } \\
\text { mean (SD), m }\end{array}$ & 406 (98) & $322(142)$ \\
\hline $\begin{array}{l}\text { C-reactive protein, median } \\
\text { (interquartile range), mg/L }\end{array}$ & $3.1(4)^{\mathrm{a}}$ & $3.4(5.8)^{\mathrm{b}}$ \\
\hline BMI, mean (SD), $\mathrm{kg} / \mathrm{m}^{2}$ & $28.5(5.1)$ & $26.1(6.7)$ \\
\hline \multicolumn{3}{|c|}{ Subject medication profile at baseline } \\
\hline Short-acting $\beta_{2}$-agonist, n (\%) & $34(6 I)$ & $40(77)$ \\
\hline Long-acting $\beta_{2}$-agonist, n (\%) & $3(5)$ & $3(6)$ \\
\hline Inhaled steroid, n (\%) & $4(7)$ & $10(19)$ \\
\hline $\begin{array}{l}\text { Combination of inhaled } \\
\text { corticosteroid and long- } \\
\text { acting } \beta_{2} \text {-agonist, } \mathrm{n}(\%)\end{array}$ & $38(68)$ & $39(75)$ \\
\hline Anticholinergic, $n(\%)$ & $39(76)$ & $45(86)$ \\
\hline Oral steroid, n (\%) & $I(2)$ & $5(10)$ \\
\hline Theophylline, n (\%) & I (2) & I (2) \\
\hline
\end{tabular}

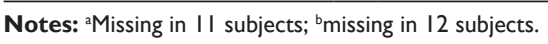

Abbreviations: BODE, Body mass index, aifflow Obstruction, Dyspnea, and Exercise capacity; BMI, body mass index; $\mathrm{FEV}_{1}$, forced expiratory volume in I second; GOLD, Global initiative for chronic Obstructive Lung Disease; SD, standard deviation.

were initiated to investigate possible COPD exacerbations of which 265 met the Anthonisen criteria. Characteristics of exacerbations confirmed during the study are reported in Table 2.

\section{Colds and COPD exacerbations}

The numbers of exacerbations in the four study periods are shown in Table 3.

In the 84 participants who had at least 1 exacerbation, 1 cold and 1 cold-free period, the relative risk of having an exacerbation was 30.4 (95\% confidence interval [CI]: 20, 47; $P<0.001)$ when a cold was present compared to when a cold was not present. The population mean risk of exacerbation increased 1.3 times (95\% CI: $1.3,1.4 ; P<0.001)$ for each cold that occurred.

Among 262 COPD exacerbations with complete information on cold symptoms and virus detection, 217 had CLS present for $\geq 1$ day at their inception while 45 did not. Exacerbations did not occur when CLS were present on 167 occasions. Thus, the presence of CLS in a participant had 
Table 2 Encounters initiated and characteristics of exacerbations

\begin{tabular}{|c|c|c|}
\hline Characteristics of COPD exacerbations & $\begin{array}{l}\text { GOLD stages I and II } \\
\text { subjects }(n=56)\end{array}$ & $\begin{array}{l}\text { GOLD stages III and IV } \\
\text { subjects }(n=52)\end{array}$ \\
\hline Number of participant encounters initiated & 121 & 146 \\
\hline Number of exacerbations meeting Anthonisen criteria & 119 & 146 \\
\hline Level 3, n (\%) & $28(24)$ & $22(15)$ \\
\hline Level 2, n (\%) & $39(33)$ & $44(30)$ \\
\hline Level I, n (\%) & $52(43)$ & $80(55)$ \\
\hline Participants experiencing no exacerbations & 11 & 7 \\
\hline Participants experiencing one exacerbation & 14 & 16 \\
\hline Participants experiencing two exacerbations & 11 & 6 \\
\hline Participants experiencing three exacerbations & 6 & 8 \\
\hline Participants experiencing four exacerbations & 8 & 6 \\
\hline Participants experiencing five or more exacerbations & 6 & 9 \\
\hline Exacerbations requiring intervention by a health professional, $n(\%)$ & $74(61)$ & $97(66)$ \\
\hline Exacerbations with a visit to a respiratory physician, $n(\%)$ & $11(9)$ & $38(26)$ \\
\hline Exacerbations with a visit to a family physician, $\mathrm{n}(\%)$ & $47(39)$ & $33(23)$ \\
\hline Exacerbations with a hospital emergency department visit, n (\%) & $13(11)$ & $22(15)$ \\
\hline Exacerbations with hospital admission, $\mathrm{n}(\%)$ & $7(6)$ & $18(12)$ \\
\hline Exacerbations without hospitalization but with prednisone initiated, n (\%) & $26(21)$ & $56(38)$ \\
\hline Exacerbations without hospitalization but with antibiotic initiated, $\mathrm{n}(\%)$ & $77(64)$ & $101(69)$ \\
\hline Exacerbations positive for virus, $n(\%)^{a}$ & $50(4 I)$ & $56(39)$ \\
\hline Exacerbations with self-reported CLS at encounter date, $n(\%)^{b}$ & $102(86)$ & $116(79)$ \\
\hline $\begin{array}{l}\text { Absolute decline in post-bronchodilator \% predicted } \mathrm{FEV}_{1} \text { at } \\
\text { exacerbation from baseline, mean }(\mathrm{SD})^{c}\end{array}$ & $6.0(8.4)$ & $0.56(7.2)$ \\
\hline
\end{tabular}

Note: a One exacerbation in GOLD I-II had unknown virus detection; 'one exacerbation encounter in GOLD I-II and one in GOLD III-IV had missing information on CLS; cbased on II6 exacerbations in GOLD I-II and I39 in GOLD III-IV.

Abbreviations: COPD, chronic obstructive pulmonary disease; CLS, cold-like symptoms; GOLD, Global initiative for chronic Obstructive Lung Disease; SD, standard deviation.

a positive predictive value of $57 \%$ for an exacerbation to develop. Overall, the sensitivity of "CLS present" for occurrence of an exacerbation was $83 \%$.

\section{Virus detection and CLS association with exacerbations}

Details of virus detection during exacerbations in this study have been published previously. ${ }^{15,16}$ Among 262 COPD

Table 3 Association of chronic obstructive pulmonary disease exacerbations with the presence of subject-reported colds

\begin{tabular}{|c|c|c|c|c|c|}
\hline \multirow[t]{2}{*}{ Study period } & \multirow{2}{*}{$\begin{array}{l}\text { Subjects } \\
\text { (n) }\end{array}$} & \multicolumn{4}{|c|}{ Exacerbations } \\
\hline & & Number & $\begin{array}{l}\text { Early } \\
\text { onset } \\
(\%)^{a}\end{array}$ & $\begin{array}{l}\text { Late } \\
\text { onset } \\
(\%)^{b}\end{array}$ & $\begin{array}{l}\text { Number } \\
\text { without } \\
\text { cold (\%) }\end{array}$ \\
\hline $\begin{array}{l}\text { December I, } 2006 \text {, } \\
\text { to April 30, } 2007\end{array}$ & 46 & 70 & $30(43)$ & $23(33)$ & $17(24)$ \\
\hline $\begin{array}{l}\text { December I, } 2007 \text {, } \\
\text { to April 30, } 2008\end{array}$ & 49 & 49 & $25(5 \mathrm{I})$ & $9(18)$ & $15(3 \mathrm{I})$ \\
\hline $\begin{array}{l}\text { December I, } 2008 \text {, } \\
\text { to April 30, } 2009\end{array}$ & 76 & 92 & $50(54)$ & $9(10)$ & $33(36)$ \\
\hline May I, 2008 , to & 74 & 51 & $26(5 I)$ & $7(14)$ & $18(35)$ \\
\hline \multicolumn{6}{|l|}{ November 30, 2008} \\
\hline Total & & $262^{c}$ & $|3|(50)$ & $48(18)$ & $83(32)^{d}$ \\
\hline
\end{tabular}

Note: ${ }^{a}$ Exacerbations that occurred within the first 3 days of a cold; bexacerbations that occurred after the first 3 days of a cold; 'three additional exacerbations occurred in which the presence of CLS or virus was not determined; ${ }^{1} 9$ of these 83 exacerbations subjects reported CLS the day prior to exacerbation detection. Abbreviation: CLS, cold-like symptoms. exacerbations meeting Anthonisen criteria and with complete cold and virus information, 79 (44\%) of 179 exacerbations with coincident colds were virus positive, as were $26(31 \%)$ of the 83 exacerbations without colds.

\section{Symptom severity score during exacerbations}

Figure 1 shows the distribution of symptom scores during COPD exacerbations that were virus- and cold positive, when virus negative with a cold present, when virus positive with no cold, and when neither virus nor cold were present, divided for the four study periods.

Compared to exacerbations that were both virus and cold negative $(\mathrm{n}=58)$, the mean increase in composite symptom score in those both virus and cold positive $(\mathrm{n}=79)$ was 0.93 (95\% CI: $0.61,1.25 ; P<0.001$ ), in virus negative and cold positive (n=100) 0.51 (95\% CI: $0.21,0.81 ; P<0.001)$, and in virus positive and cold negative $(\mathrm{n}=26) 0.58(95 \% \mathrm{CI}$ : $0.23,0.94 ; P<0.001)$. These data are shown graphically in Figure 2.

Compared to when no cold was present, the mean symptom score in early colds ( $<3$ days of cold symptoms) increased by 0.59 ( $95 \% \mathrm{CI}: 0.34,0.85 ; P<0.001$ ), in later ( $\geq 3$ days of cold symptoms) 0.27 ( $95 \% \mathrm{CI}:-0.01,0.56 ; P=0.06$ ), and between early and later colds by 0.32 (95\% CI: $0.00,0.64$; $P=0.05$ ). 


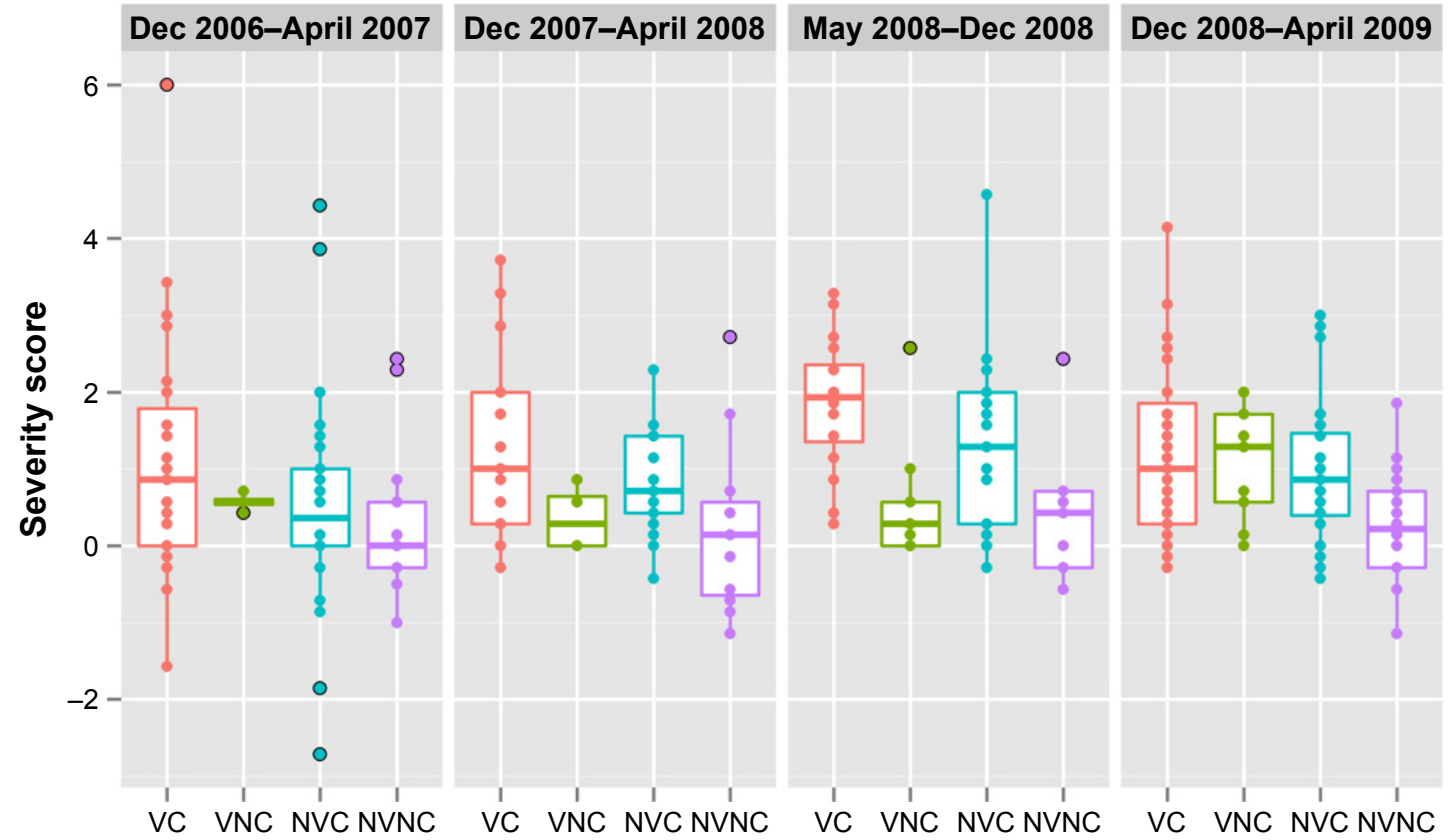

Figure I The distributions of composite respiratory symptom scores and their medians and quartiles within four study periods.

Notes: Scores are grouped in four categories of chronic obstructive pulmonary disease exacerbation: those with colds being virus positive (VC), those with virus present but no apparent cold (VNC), those with no virus present but a cold reported (NVC), and those with neither virus nor cold present (NVNC).

\section{Discussion}

More than $50 \%$ of colds are associated with infections of HRV ${ }^{19}$ and studies of experimental inoculation of COPD patients demonstrate that HRV can trigger worsening of respiratory symptoms typical of exacerbations. ${ }^{18,20}$ In a prospective study of

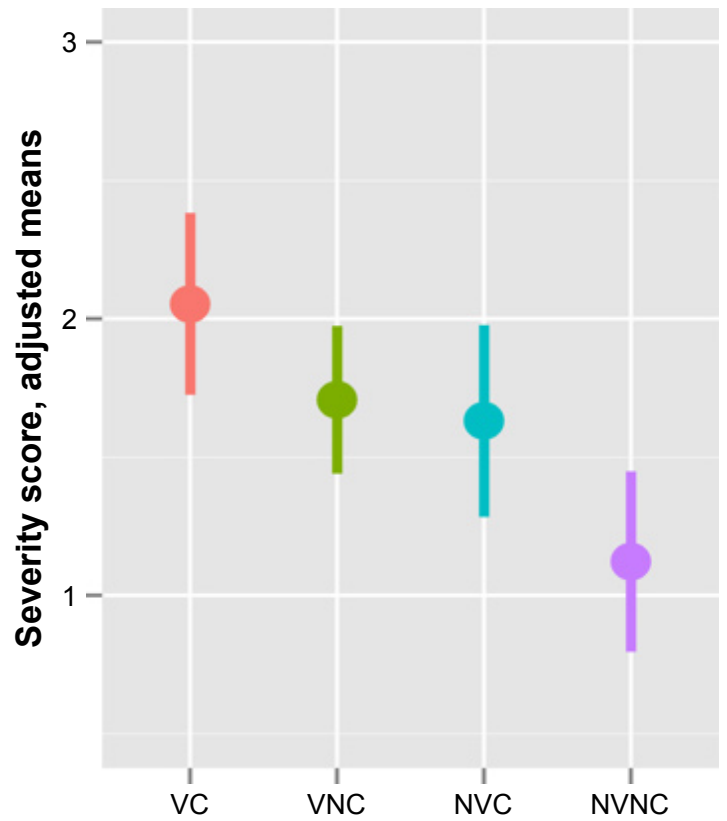

Figure $\mathbf{2}$ The adjusted mean composite respiratory symptom scores and their $95 \%$ confidence intervals across all four periods of the study.

Notes: Scores are grouped in four categories of chronic obstructive pulmonary disease exacerbation: those with colds being virus positive (VC), those with virus present but no apparent cold (VNC), those with no virus present but a cold reported (NVC), and those with neither virus nor cold present (NVNC).
COPD patients, the presence of rhinorrhea was shown to be the respiratory symptom that was most predictive of exacerbation development. ${ }^{8}$ It has also been reported that COPD patients have increased susceptibility to respiratory virus infections and worse symptoms when these occur through weakened host defense mechanisms. ${ }^{21}$ A study conducted by Hurst et a ${ }^{13}$ concluded that frequent exacerbators, those having a number of exacerbations above the median in the study cohort, experienced approximately double the number of colds than those having a number of exacerbations below the median number.

We wished to determine to what extent the presence of a cold increased the probability of an exacerbation occurring and if respiratory symptoms were worse during an exacerbation when a cold and/or a respiratory virus were present.

We acknowledge that detection of CLS in our study was predicated on a categorical response to a single question in a daily electronic report. We also recognize that we included in the examples of cold symptoms in the questionnaires "Runny/stuffy nose, change in phlegm color or stickiness, sore throat, fever, shivers, chest congestion" that some of these are not specific to colds and may occur during exacerbations in which colds were not present. However, in all cases, the reported presence of either cold symptoms or worsening respiratory symptoms suggestive of a COPD exacerbation triggered contact with the participant to confirm the nature of the event and if the presence of a cold or exacerbation was confirmed to schedule an in-home encounter to collect further data and specimens for testing. We made every effort during 
dialogue with participants before scheduling an encounter to ascertain the nature of the event, cold/RI or exacerbation, but it is possible that complete discrimination did not occur and our results should be interpreted recognizing this.

While the respiratory symptom severity scores related to the presence of CLS included in this report are of interest, we believe that they will require confirmation using a COPD symptom questionnaire index of proven validity such as EXACT.$^{22}$ However, the utility of EXACT for the detection of COPD exacerbations has been questioned, as the questionnaire detected but $28 \%$ of exacerbations found using diary cards in the East London COPD cohort. ${ }^{23}$ It is conceivable that changes in the severity of lower respiratory tract symptoms alone may not be adequately sensitive for detection of the onset of COPD exacerbations.

The magnitude of the increased risk of exacerbation we found associated with the onset of colds in COPD patients, over 30 -fold compared to cold-free periods, is clinically important. While such a risk suggests that the importance to COPD patients of avoiding exposure to RIs should be emphasized, this has to be balanced against the importance of socialization to overall health and well-being. The benefit of ensuring that COPD patients receive annual influenza immunization is obvious as are basic hygiene procedures. We have confirmed in a study in which all exacerbations were investigated that the presence of apparent colds in COPD patients is associated with both increased risk of exacerbations and greater severity of these when they occur. As such, CLS, when detected and reported by COPD patients, should initiate watchfulness on the part of health care providers to reduce the possibility of major intervention being required.

As observed by others, ${ }^{12,14}$ we found that symptom severity during exacerbations associated with a cold was worse than in those without. Furthermore, symptom severity was worse still in those exacerbations coinciding with a cold in which a respiratory virus was detected. It is possible that viruses were present in more exacerbations than those in which we detected them, but the proportions of exacerbations in which respiratory viruses were detected in our study are consistent with the findings of others. ${ }^{24}$

While $68 \%$ of exacerbations coincided with a symptomatic cold as per our definition, the proportion of exacerbations associated with the presence of at least 1 day of CLS at their inception was even higher $(83 \%)$. These figures are both considerably higher than the PCR detection rate of respiratory viruses at exacerbation (40\%). Some previous studies have used the frequency of PCR detection of respiratory viruses at exacerbation as an indication of the proportion of exacerbations which are related to upper respiratory tract viral infections. ${ }^{25,26}$
Our findings suggest that the proportion of exacerbations linked to apparent colds may be considerably greater than previously estimated using viral detection methods. Early detection and reporting of CLS whatever the cause is a sensitive predictor of exacerbation risk. Also in this study, $50 \%$ of all exacerbations began in the first 3 days of a cold (Table 3 ), which emphasizes the importance of ensuring effective communication between COPD patients and those responsible for their care.

There is a growing international burden of COPD and particularly COPD exacerbations on health systems. Between 1969 and 2013 in the United States, the all-cause age standardized death rate per 100,000 population decreased from 1,278 to 730 . That for COPD doubled from 21 to 42 per $100,000 .{ }^{27}$ The direct costs of health care in the USA for COPD victims in 2005 dollars was $\$ 21.8$ billion or a range of $\$ 2,700-\$ 5,900$ per patient annually. ${ }^{28}$ In addition, COPD is underdiagnosed. In a prospective study of a population sample of more than 8,000 subjects aged $\geq 35$ years in the UK, $13.2 \%$ were found to have spirometrically diagnosed COPD. Among those, $>80 \%$, including many with severe deficits in respiratory function, did not have a diagnosis of respiratory disease. ${ }^{29}$

Our prospective study of COPD patients is distinguished from others by these features: symptom data were collected and validated daily throughout the study; all exacerbations were detected and evaluated at or near their inception; statistical modeling of the relation of COPD exacerbations to colds optimized understanding of the relationship.

\section{Conclusion}

A large majority of COPD exacerbations occur following the appearance of CLS. The risk of having an exacerbation in individuals increases by 30 -fold when colds are present. Respiratory symptoms during exacerbations that coincide with colds are more severe than exacerbations with no cold present. Respiratory viruses were only detected in approximately half of the reported apparent colds.

\section{Acknowledgments}

This study was supported by an unrestricted grant from AstraZeneca PLC. Preliminary data from this study were included in an abstract (1105) accepted for the European Respiratory Society 2015 Meeting and presented in a poster at the European Respiratory Society International Congress in Amsterdam, The Netherlands, September 26th to 30th, 2015. ${ }^{30}$

\section{Author contributions}

Mr Johnston is the guarantor of this report, led the study design team, supervised the conduct of the study, and drafted the manuscript. Dr McIvor clinically assessed study 
patients, led patient recruitment, and co-supervised conduct of the original clinical study. Drs Gerhardsson de Verdier, Gustafson, Edsbacker, and Mr McCrae provided intellectual guidance throughout the study's inception, design, and conduct. Professor Coyle supervised and interpreted virological testing for the study. Dr Olsson designed and conducted the statistical analyses. All authors contributed toward data analysis, drafting and critically revising the paper, gave final approval of the version to be published, and agree to be accountable for all aspects of the work.

\section{Disclosure}

Mr Johnston has received research funding and/or honoraria from Merck Canada, Inc., GlaxoSmithKline Canada, and AstraZeneca PLC. Dr McIvor has received honoraria from pharmaceutical companies, including AstraZeneca, Boehringer Ingelheim, Takeda, Pfizer, Merck, and GlaxoSmithKline for educational events, advisory boards, and Phase 3 clinical trials. Authors Gerhardsson de Verdier, Gustafson, McCrae, Edsbäcker, and Olsson are employed by AstraZeneca and own shares in the company. Professor Coyle has received honoraria from pharmaceutical companies (Roche, Randox, and Abbott) for educational events, advisory boards, and is a founding director of the start-up company Hibergene. The authors report no other conflicts of interest in this work.

\section{References}

1. Dhamane AD, Moretz C, Zhou Y, et al. COPD exacerbation frequency and its association with healthcare resource utilization and costs. Int $J$ Chron Obstruct Pulmon Dis. 2015;10:2609-2618.

2. Hurst JR, Vestbo J, Anzueto A, et al. Susceptibility to exacerbation in chronic obstructive pulmonary disease. $N$ Engl J Med. 2010;363(12): $1128-1138$

3. Johnston SL. Overview of virus-induced airway disease. Proc Am Thorac Soc. 2005;2(2):150-156

4. Upshur RE, Knight K, Goel V. Time-series analysis of the relation between influenza virus and hospital admissions of the elderly in Ontario, Canada, for pneumonia, chronic lung disease, and congestive heart failure. Am J Epidemiol. 1999;149(1):85-92.

5. Rohde G, Wiethege A, Borg I, et al. Respiratory viruses in exacerbations of chronic obstructive pulmonary disease requiring hospitalisation: a case-control study. Thorax. 2003;58(1):37-42.

6. Nicholson KG, Kent J, Ireland DC. Respiratory viruses and exacerbations of asthma in adults. BMJ. 1993;307(6910):982-986.

7. Seemungal TA, Harper-Owen R, Bhowmik A, et al. Respiratory viruses, symptoms, and inflammatory markers in acute exacerbations and stable chronic obstructive pulmonary disease. Am J Respir Crit Care Med. 2001; 164(9):1618-1623.

8. Hutchinson AF, Ghimire AK, Thompson MA, et al. A community-based, time-matched, case-control study of respiratory viruses and exacerbations of COPD. Respir Med. 2007;101(12):2472-2481.

9. Zwaans WAR, Mallia P, van Winden MEC, Rohde GG. The relevance of respiratory viral infections in the exacerbations of chronic obstructive pulmonary disease - a systematic review. J Clin Virol. 2014;61: 181-188.
10. Sethi S. Infectious etiology of acute exacerbations of chronic bronchitis. Chest. 2000;115(5 suppl 2):380S-385S.

11. Seemungal TAR, Donaldson GC, Bhowmik A, et al. Time course and recovery of exacerbations in patients with chronic obstructive pulmonary disease. Am J Respir Crit Care Med. 1999;161(5):1608-1613.

12. Aaron SD, Donaldson GC, Whitmore GA, et al. Time course and pattern of COPD exacerbation onset. Thorax. 2012;67(3):238-243.

13. Hurst JR, Donaldson TMA, Wilkinson WR, Perera WR, Wedzicha JA. Epidemiological relationships between the common cold and exacerbation frequency in COPD. Eur Respir J. 2005;26(5):846-852.

14. Wedzicha JA, Brill SE, Allinson JP, Donaldson GC. Mechanisms and impact of the frequent exacerbator phenotype in chronic obstructive pulmonary disease. BMC Medicine. 2013;11:181-191.

15. Johnston NW, McIvor RM, Lambert K, et al. The Christmas season as a risk factor for COPD exacerbations. Can Respir J. 2010;17(6): 275-281.

16. Johnston NW, Lambert K, Hussack P, et al. Detection of COPD exacerbations and compliance with patient reported daily symptom diaries using a smartphone-based information system. Chest. 2013;144(2): 507-514.

17. Anthonisen NR, Manfreda J, Warren CP, et al. Antibiotic therapy in exacerbations of chronic obstructive pulmonary disease. Ann Intern Med. 1987;106(2):196-204.

18. Mallia P, Message SD, Gielen V, et al. Experimental rhinovirus infection as a human model of chronic obstructive pulmonary disease exacerbation. Am J Resp Crit Care Med. 2011;183(6):734-742.

19. Friedlander SL, Busse WW. The role of rhinovirus in asthma exacerbations. J Allergy Clin Immunol. 2005;116(2):267-273.

20. Gunawardana N, Finney L, Johnston SL, Mallia P. Experimental rhinovirus infection in COPD: implications for antiviral therapies. Antiviral Res. 2014;102:95-105.

21. Sajjan US. Susceptibility to viral infections in chronic obstructive pulmonary disease: role of epithelial cells. Curr Opin Pulm Med. 2013; 19(2):125-132.

22. Leidy NK, Wilcox TK, Jones PW, et al. Standardizing measurement of chronic obstructive pulmonary disease exacerbations. Am J Crit Care Med. 2011;183(3):323-329.

23. Mackay AJ, Donaldson GC, Anant RC, Singh R, Kowlessar B, Wedzicha JA. Detection and severity grading of COPD exacerbations using the exacerbations of chronic pulmonary disease tool (EXACT). Eur Respir J. 2014;43:735-744.

24. Hewitt R, Farne H, Luke E, Johnston SL, Mallia P. The role of viral infections in exacerbations of chronic obstructive pulmonary disease and asthma. Ther Adv Respir Dis. 2016;10(2):158-174.

25. Kurai TS, Saraya T, Ishii H, Takizawa $H$. Virus induced exacerbations in asthma and COPD. Frontiers in microbiology. 2013;4:1-12.

26. Wark PAB, Tooze M, Powell H, et al. Viral and bacterial infection in acute asthma and chronic obstructive disease increases the risk of readmission. Respirology. 2013;18:996-1002.

27. Ma J, Ward EM, Siegel RI, Jemal A. Temporal trends in mortality in the United States, 1969-2013. JAMA. 2015;314(16):1731-1739.

28. Foster TS, Miller JD, Marton JP, Caloyeras JP, Russell MW, Menzin J. Assessment of the economic burden of COPD in the U.S.: a review and synthesis of the literature. COPD. 2006;3(4):211-218.

29. Shahab I, Jarvis MJ, Britton J, West R. Prevalence, diagnosis and relation to tobacco dependence of chronic obstructive pulmonary disease in a nationally representative population sample. Thorax. 2006;61(12): 1043-1047.

30. Johnston NW, Olsson M, Edsbacker S, et al. Relationship of cold frequency and virus detection to exacerbations in COPD patients. Poster presented at: European Respiratory Society International Congress; September 26-30, 2015; Amsterdam, The Netherlands. 


\section{Supplementary materials}

\section{STUDY OF CYCLIC EPIDEMICS OF COPD EXACERBATION}

\section{*DAILY QUESTIONNAIRE*}

\begin{tabular}{|c|c|}
\hline Complete this form on: 21 Sep 2006 & Example: $\square$ Correct $\square$ Incorrect \\
\hline $\begin{array}{l}\text { 1. How often did you cough in the last } 24 \text { hours? } \\
\text { (Fill in one box) }\end{array}$ & $\begin{array}{l}\square \text { Not at all } \\
\square \text { Very little } \\
\square \text { Several times } \\
\square \text { Frequently } \\
\square \text { Most of the time }\end{array}$ \\
\hline $\begin{array}{l}\text { 2. How often were you short of breath or felt } \\
\text { breathless in the last } 24 \text { hours? } \\
\text { (Fill in one box) }\end{array}$ & $\begin{array}{l}\square \text { Not at all } \\
\square \text { Very little } \\
\square \text { Several times } \\
\square \text { Frequently } \\
\square \text { Most of the time }\end{array}$ \\
\hline $\begin{array}{l}\text { 3. How much sputum/phlegm did you cough } \\
\text { up in the last } 24 \text { hours? } \\
\text { (Fill in one box) }\end{array}$ & $\begin{array}{l}\square \text { None at all } \\
\square \text { Less than usual } \\
\square \text { Usual amount } \\
\square \text { More than usual } \\
\square \text { Much more }\end{array}$ \\
\hline $\begin{array}{l}\text { 4. How many times (not puffs) did you use your } \\
\text { rescue or reliever inhaler for a breathing problem } \\
\text { in the last } 24 \text { hours? } \\
\text { (Fill in one box) }\end{array}$ & $\begin{array}{l}\square 0 \\
\square 1 \text { to } 3 \\
\square 4 \text { to } 6 \\
\square 7 \text { to } 9 \\
\square \text { Greater than or equal to } 10\end{array}$ \\
\hline $\begin{array}{l}\text { 5. Did you have any cold or flu symptoms such as } \\
\text { runny/stuffed up nose, change in phlegm colour or } \\
\text { stickiness, sore throat, fever, shivers, wheeze, } \\
\text { chest congestion, feeling unwell? }\end{array}$ & $\begin{array}{l}\square \text { Yes } \\
\square \text { No }\end{array}$ \\
\hline $\begin{array}{l}\text { 6. Did you see a health professional in a doctor's } \\
\text { office, walk-in clinic, hospital or emergency } \\
\text { department for a breathing problem? }\end{array}$ & $\begin{array}{l}\square \text { Yes } \\
\square \text { No }\end{array}$ \\
\hline
\end{tabular}

7. Did you have any other problems or anything you want to tell the study team?

Do not write outside this box.

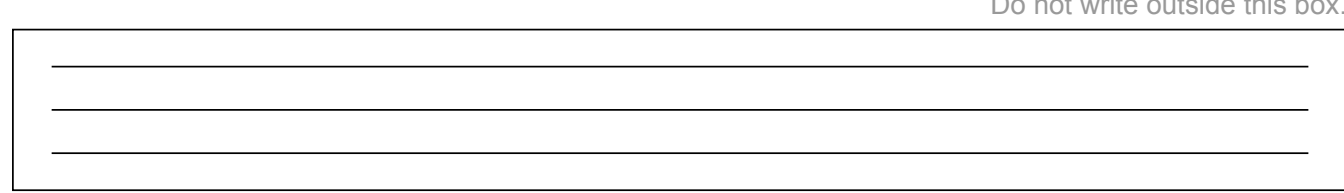

Thank you for helping us with this important study.

WWW.HealthDiary.ca

101060921

Figure SI Fax daily diary form. 
Table SI BlackBerry daily diary

\begin{tabular}{|c|c|c|}
\hline \multirow{2}{*}{$\begin{array}{l}\text { Variable } \\
\text { name }\end{array}$} & Question & \multirow[t]{2}{*}{ Response } \\
\hline & Daily diary & \\
\hline $\begin{array}{l}\text { Subject } \\
\text { number }\end{array}$ & Subject identification number & \\
\hline Subject initial & Subject initial & \\
\hline \multirow[t]{5}{*}{ Diary QI } & Did you cough today? & No cough \\
\hline & & Mild cough \\
\hline & & Moderate cough \\
\hline & & Severe cough \\
\hline & & Very severe cough \\
\hline \multirow[t]{5}{*}{ Diary Q2 } & Did you have shortness of breath or feel breathless today? & No shortness of breath \\
\hline & & Mild shortness of breath \\
\hline & & Moderate shortness of breath \\
\hline & & Severe shortness of breath \\
\hline & & Very severe shortness of breath \\
\hline \multirow[t]{3}{*}{ Diary Q3 } & What color was your phlegm today? & Did not cough up phlegm \\
\hline & & Clear or white or milky \\
\hline & & Deep yellow or green \\
\hline \multirow[t]{3}{*}{ Diary Q4 } & How would you describe your overall health today? & Better than usual \\
\hline & & About the same as usual \\
\hline & & Worse than usual \\
\hline \multirow[t]{2}{*}{ Diary Q5 } & Have you had any of the symptoms of a cold or flu? & No, have not had any cold or flu symptoms \\
\hline & & Yes, have a sore throat, fever, shivers, or chest congestion \\
\hline \multirow[t]{2}{*}{ Diary Q6 } & Did you see a doctor or nurse today for breathing & No \\
\hline & problems or a cold? & Yes \\
\hline \multirow[t]{2}{*}{ Diary Q7 } & Is there anything that you'd like the study team to contact & No \\
\hline & you about? & Yes \\
\hline \multirow[t]{2}{*}{ Diary Q8 } & Did you take prednisone today? & No \\
\hline & & Yes \\
\hline \multirow[t]{2}{*}{ Diary Q9 } & Did you take an antibiotic today? & No \\
\hline & & Yes \\
\hline \multirow[t]{3}{*}{ Diary QI0 } & Do you think your breathing is back to normal today? & No \\
\hline & & Yes \\
\hline & & Don't know \\
\hline Diary date & Date of diary & Date \\
\hline
\end{tabular}

Abbreviation: Q, question.

\section{Publish your work in this journal}

The International Journal of COPD is an international, peer-reviewed journal of therapeutics and pharmacology focusing on concise rapid reporting of clinical studies and reviews in COPD. Special focus is given to the pathophysiological processes underlying the disease, intervention programs, patient focused education, and self management protocols.
This journal is indexed on PubMed Central, MedLine and CAS. The manuscript management system is completely online and includes a very quick and fair peer-review system, which is all easy to use. Visit http://www.dovepress.com/testimonials.php to read real quotes from published authors. 